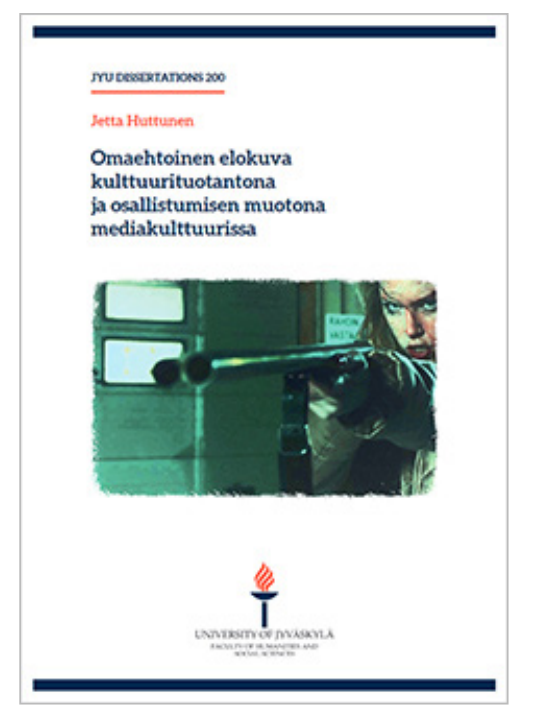

\section{OMAEHTOISTA ELOKUVAA JÄLJITTÄMÄSSÄ}

Jetta Huttunen (2020) Omaehtoinen elokuva kulttuurituotantona ja osallistumisen muotona mediakulttuurissa. JYU Dissertations 200. Jyväskylä: Jyväskylän yliopisto, 114 s. + alkuperäisartikkelit.
Jetta Huttusen kulttuurintutkimuksen alan artikkeliväitöskirja Omaehtoinen elokuva kulttuurituotantona ja osallistumisen muotona mediakulttuurissa tarttuu aiheeseen, jota on Suomessa tutkittu vähän: vakiintuneen elokuvakentän ulkopuoliseen tuotantoon. Ilman Suomen Elokuvasäätiön tukea tuotettujen elokuvateatterissa esitettyjen elokuvien määrä on ollut viime vuosina $20-25 \%$ ensi-illoista. Se on yllättävänkin paljon. Tutkimus sijoittuu laajempaan maisemaan, jossa raja kulttuurin tuottajiin ja sen kuluttajiin on hämärtymässä. Tämä sumea alue on kiinnostava.

Väljästi asetettu tutkimustehtävä kuuluu: Millaista on omaehtoisten tekijöiden osallistuminen kulttuurituotantoon ja millaiseksi omaehtoisen elokuvan paikka muodostuu julkisuudessa?

Tutkimuksella on pitkä aikajänne, syksystä 2006 viime vuoteen. Kuten tutkija huomauttaa, pitkällä ajanjaksolla on sekä hyviä että huonoja puolia. Ilmiö on ehtinyt tänä aikana muuttua, mikä tulee ilmi kiinnostavalla tavalla aineistossa. Toisaalta ensimmäisten artikkelien kaikki havainnot eivät ehkä enää ole relevantteja.

Riippumaton (independent) tarkoittaa yleisesti elokuvaa, jossa tekijällä on täysi kontrolli teokseensa tekoprosessista jakeluun. Käytännössä termillä on tarkoitettu studiosysteemin tai institutionaalisen järjestelmän ulkopuolisia tuotantoja. Termiä on käytetty myös esteettisenä kategoriana (Michael Newman). Koska "riippumaton" on enemmänkin järjestelmän synnyttämä käsite, Huttunen ottaa käyttöön termin "omaehtoinen" kuvatakseen vaihto- ehtoista tai marginaaliin sijoittuvaa tuotantoa Suomessa. Tällainen omaehtoisuus voi ilmetä joko harrastajatuotantona tai ammattimaisuuteen pyrkivänä pientuotantona.

Aineistona on toisaalta keskustelut harrastajatekijöiden keskustelufoorumeilla 2007-2013 ja toisaalta pientuottajien teemahaastattelut, joita on kuusi vuosilta 2010-2016. Tutkimus ei käytä mitään tilastollisia menetelmiä, mutta silti voisi miettiä kuinka edustava tai kattava haastateltavien valinta on. Miksi juuri nämä tekijät on valittu? Kaikki haastateltavat ovat miehiä, koska omaehtoinen elokuva on ainakin toistaiseksi miesten laji. Finfilmsin ja Indietaivaan ylläpitäjien mukaan jopa $99 \%$ nettiyhteisöjen jäsenistä oli miehiä. Muutamia naisten tekemiä omaehtoisia elokuvia kuitenkin on, kuten Huttunen huomauttaakin. Kun omaehtoisten elokuvantekijöiden joukko Suomessa on aika rajallinen, heitä olisi ehkä kannattanut haastatella laajemminkin ja hyödyntää heidän mielipiteitään, kun kerran tutkijan pyrkimyksenä on äänen antaminen tälle alakulttuurille.

Huttunen kuvaa menetelmäänsä teorialähtöiseksi laadulliseksi sisällönanalyysiksi. Hän tukeutuu osallistumisen teorioihin, joiden taustalla vaikuttaa mediatutkimuksen ja yleisötutkimuksen traditio. Taustalla on myös Birminghamin koulukunta, joka tietysti sopii hyvin tarkasteltavaan ilmiöön, onhan kyse vahvasti reviirikamppailusta.

Omaehtoiset elokuvat erottuvat tyylillisesti valtavirrasta. Ne ovat usein rosoisia ja hiomattomia. Huttunen viittaa "independentestetiikkaan". Se edellyttää katsojalta ymmär- 
tävää asennoitumista tai kuulumista yhteisöön. Monet omaehtoiset elokuvat haastavat sovinnaisen valtavirtaelokuvan rajoja. Kentällä tehdään paljon trashia, splatteria ja eksploitaatioelokuvaa. Hollywood-elokuvien parodiat ovat ilmeisesti aina olleet suosittuja, erityisesti kun kohteena on scifi, kauhu ja toimintaelokuvat. Tekijät kokevat elokuviensa tarjoavan valtavirtaelokuvaa rohkeampaa ja rajumpaa sisältöä - ja olevan näin vaihtoehtoista. Kuten Huttunen huomauttaa, perinteistä realistista draamagenreä edustavat omaehtoiset elokuvat eivät tunnu saavan lisäarvoa omaehtoisuudestaan tai vaihtoehtoisesta tekotavastaan.

Miksi riippumaton elokuvatuotanto on tyypillisesti genre-elokuvaa, kauhua, toimintaa tai scifiä? Tätä voisi pohtia enemmänkin. Yksi selitys voisi olla se, että nämä lajityypit ovat pitkään puuttuneet suomalaiselta elokuvakentältä, mutta toisaalta indietuotanto painottuu genre-elokuvaan sellaisissakin elokuvakulttuureissa, joissa tuotetaan myös paljon genreelokuvaa.

Huttunen erottelee omaehtoisen elokuvan piirissä amatöörivoimin tehdyn harrastajaelokuvan (ensimmäinen ja toinen artikkeli) ja varsinaisen pientuotannon (kolmas artikkeli). Merkittävimmäksi eroksi näyttää nousevan jakelu. Harrastajatuotanto leviää oman yhteisön piirissä, ja julkisuutta pyritään jopa välttelemään. Elokuvia halutaan käsitellä vertaisryhmässä samalla oppien ja kehittyen. Puoliammattilainen ja varsinainen pientuottaja asemoi itsensä toisin ja ainakin pyrkii julkisuuteen. Julkisuudessa omaehtoinen tuotanto asettuu suhteeseen valtavirtatuotannon kanssa, jonka varjossa se tulee usein vähätellyksi tai saa vain vähäisen mediahuomion.

Nicholas Abercrombien ja Brian Longhurstin mukaan mediakulttuurissa fanit kehittyvät viihdekulttuurin puitteissa usein kuluttajista ja harrastajista tuottajiksi. Omaehtoisessa elokuvatuotannossa on paljon faniuden piirteitä. Monet amatöörit ovat jonkun tekijän, tyylilajin tai jopa yksittäisen elokuvan fanittajia. Siirtyminen kuluttajasta tuottajaksi tapahtuu Abercrombien ja Longhurstin mukaan juuri osallistumisen lisääntymisen kautta. Myös Huttusen esittämä hyvä kysymys on, lisääkö tämä kuluttajien ja tuottajien välisen rajan hämärtyminen aidosti mediakulttuurin demokraattisia piirteitä.
Yhteisöllisyys on muutenkin tärkeässä asemassa koko ilmiössä. Harrastajatuottajilla oli vuosina 2005-2017 oma yhdistyksensä Findie ry, joka on nyt lopettanut toimintansa. Keskustelufoorumi Indiefoorumi ajettin alas vuonna 2013. Yhtenä syynä oli Youtuben yleistyminen levityskanavana. Samalla katosivat nettiyhteisöjen tarjoamat pienyleisöt. Harrastajien kokema vahva yhteisöllisyyden kausi näyttäisi olevan jo menneisyyttä. Huttusen mukaan samaan aikaan yhteisöjen hajoamisen kanssa tapahtui riippumattomien elokuvantekijöiden ja pientuottajien esiinmarssi. Näiden harrastajista pientuottajiksi siirtyneiden tekijöiden pyrkimys erottautua amatööreistä saattaa osaltaan selittää harrastajayhteisön rapautumista. Siirryttäessä harrastajasta pientuottajaksi niin asema elokuvan kentällä kuin myös identiteetti muuttuvat, ja pientuottajat joutuvat toisenlaiseen reviirikamppailuun suhteessa valtavirtaelokuvaan.

Huttunen tunnistaa aineistostaan kiinnostavan ristiriidan: tekijät korostavat riippumattomuuttaan ja omaehtoisuuttaan, ja samanaikaisesti puheessa kuuluu vahva pyrkimys ammattilaisuuteen ja parempiin resursseihin - siis valtavirtaan. Oireellisesti aineistoista nousee esiin menestynyt Spede Pasanen jonkinlaisena riippumattomuuden esikuvana. Elokuvasäätiö ja muut vakiintuneet rahoittajat koetaan ankarina portinvartijoina.

Kaikilla haastatelluilla on av-alan koulutus. Onko se sattumaa vai oireellista suomalaiselle omaehtoiselle tuotannolle? Joku paradoksi tuntuisi olevan siinä, että Huttusen havainnoima omaehtoinen elokuvakulttuuri konkretisoituu riippumattoman elokuvantekijän pyrkimyksessä tuottaa elokuvia suurelle yleisölle. Onko niin, että suomalainen omaehtoinen tuotanto on vaihtoehtoista suhteessa suomalaisen elokuvan vakiintuneeseen tukijärjestelmään ja ekosysteemiin, muttei suinkaan suhteessa esimerkiksi kaupallisuuteen? Voiko suureen yleisömäärään tähtäävää mutta siinä mahdollisesti epäonnistuvaa elokuvaa sanoa vaihtoehtoiseksi?

Ääneen lausumatta jää ilmeinen kysymys omaehtoisen riippumattoman tuotannon luonteesta, onko se - ainakin Suomessa ja Huttusen aineiston valossa - pikemminkin välivaihe ammatillisella uralla vai aidosti vaihtoehtoista ja omaehtoista? Tämä korostuu, kun Huttusen 
haastattelemilla tekijöillä on kova halu tulla ammattilaisiksi. Omaehtoisen elokuvan tekijä on amatööri, joka pyrkii ja usein myös siirtyy ammattimaiseksi pientuottajaksi. Tällöin työtapa muuttuu, ammattinimikkeistä tulee tarkempia ja hierarkkisempia ja koko tekoprosessi ammattimaistuu. Yhteisöllisyys, vertaisryhmään kuuluminen ei ole enää niin merkityksellistä. Tällaisen omaehtoisen elokuvan tekijä ei halua enää samastua harrastajatekijöiden alakulttuuriin ja yhteisöön. Pientuottaja hakee ammattimaista statusta.

Mediatuotanto voi olla vaihtoehtoista sisällöllisesti, esteettisesti, tuotanto- ja jakelutavoiltaan tai asenteeltaan. Suomalainen omaehtoinen elokuva on vaihtoehtoista ainakin tuotantotavoiltaan ja asenteeltaan. Epäilemättä trash ja muut valtavirtaelokuvan puolelta puuttuvat lajityypit ovat vaihtoehtoisia myös sisällöllisesti. Valtavirtaelokuva on edelleen enemmän tai vähemmän realistiseen ilmaisuun nojautuvaa, kun taas omaehtoinen tuotanto osoittaa vaihtoehtoista makua tai on muuten marginaalista. "Harrastajatuottajien voidaan nähdä nauravan valtavirtaelokuvan esteettisille normeille ja jopa kritisoivan mediakulttuurissamme vallitsevaa jakoa hyvään ja huonoon elokuvaan", Huttunen kirjoittaa (s. 31). Hänen mukaansa näiden elokuvien sisältö on vaihtoehtoista, niiden tarinat ja päähenkilöt ovat sellaisia, joita ei suomalaisessa elokuvassa yleensä nähdä.

Merkittävä ero valtavirtaan on tietenkin se, että elokuvat on tehty hyvin pienillä budjeteilla ja valtaosin talkootyöllä. Kyse on sekä aineellisista että symbolisista resursseista. Onko omaehtoinen elokuva sitten alakulttuuria vai vastakulttuuria? Huttunen viittaa Adornon ja Benjaminin (kapitalistiseen) kulttuuriteollisuuteen kohdistuvaan kritiikkiin. Vastakulttuuri haastaisi aktiivisesti valtakulttuuria. Tekeekö omaehtoinen elokuvatuotanto sitä? Huttusen mukaan omaehtoinen tuotanto kamppailee niin resursseista kuin julkisuudestakin valtakulttuurin kanssa pyrkien murtamaan valtakulttuurin hegemoniaa. Se haastaa "massatuotetun viihdeteollisuuden omilla tuotteillaan populaarikulttuurin piirissä", Huttunen kirjoittaa (s. 51). Hän ei tarkastele omaehtoista elokuvaa ideologisesti, joka toki olisi kiinnostavaa vaikkapa Adornon ja Benjaminin hengessä.
Väitöskirja on hieman toisteinen, mikä on usein tyypillistä artikkeliväitöskirjoille. Jokunen virhekin on tekstiin lipsahtanut. AVEK ei myönnä tukea pitkille fiktioelokuville, päinvastoin kuin kirjoittaja väittää. Ei pidä myöskään paikkaansa, että Spede Pasasen tuottamat elokuvat eivät olisi saaneet lainkaan julkista tukea 1970- ja 1980-luvuilla. Ne saivat sekä elokuvan laatutukea että elokuvasäätiön tukea. Asia ilmenee esimerkiksi Kalle Kinnusen kirjoittamasta säätiön historiasta (Elokuvasäätiön tuella - Suomalaista elokuvaa tekemässä 1969-2019, 2019).

Omaehtoinen tuotanto on tehnyt hyvää kotimaiselle elokuvalle. Kuten Huttunen (s. 48) kirjoittaa: "Omaehtoinen elokuvatuotanto on pientuottajuutta, joka muuttaa kulttuurintuotannon rakenteita ja jonka vaikutus mediakulttuurin tuotantoprosesseihin on merkittävä." Se on ilmiönä jo nyt monipuolistanut suomalaisen elokuvan kenttää ja laventanut tarjontaa. Se on myös vaikuttanut siihen, että genre-elokuvat ja aiemmin harvinaiset lajityypit ovat päässeet julkisen tuen piiriin. Monista omaehtoisista tekijöistä on myös tullut vakiintuneita ja menestyneitä ammattilaisia. He eivät siis enää ole omaehtoisia, mutta ilmeisesti ja toivottavasti uutta väkeä on tulossa.

\section{Jouko Aaltonen}

TaT, elokuvaohjaaja, Aalto-yliopisto 